\title{
PREDIKSI DISTRIBUSI PENCEMARAN AIR SUNGAI BRANTAS HULU KOTA BATU PADA MUSIM HUJAN DAN KEMARAU MENGGUNAKAN METODE SPASIAL INVERSE DISTANCE WEIGHTED
}

\author{
Novia Lusiana ${ }^{\left.1^{*}\right)}$, Bambang Rahadi ${ }^{2)}$ \\ ${ }^{1)}$ Program Studi Teknik Lingkungan, Fakultas Teknologi Pertanian, Universitas Brawijaya \\ ${ }^{2}$ Program Studi Teknik Lingkungan, Fakultas Teknologi Pertanian, Universitas Brawijaya \\ *Email : novialusiana88@gmail.com
}

\begin{abstract}
The diversity of activities along the Brantas watershed causes waste disposal, which contributes to an increase in pollution load in the Brantas watershed and a decrease in water quality. It is necessary to periodically monitor water quality changes, but the constraints faced are the high cost of sample testing. The solution that can be done is to predict changes in water quality through the neighborhood method to reduce the number of samples. The purpose of this study is to predict the water quality conditions spatially by using the Inverse Distance Weighted (IDW) method, especially in the watershed area of Batu Upper Brantas and find out the differences in the spread of pollution water in the conditions of the rainy and dry season, as the last output is to determine the water purification zone. The IDW method is able to visualize the spread of water pollution with distance-based interpolation calculations, where the advantages of IDW compared to other methods are that the calculations are at the minimum limit and the maximum limit of input values. The results obtained from this study were from 13 sampling points obtained 1 point experienced an increase in pollution status in the rainy season to dry season, namely from weight to moderate, 1 sample point that experienced changes in pollution status from mild to moderate, 7 points experienced a change in status from moderate to severe and 4 sample points experiencing changes in status from mild to severe. Branats River degradation zone upstream of Batu City at a distance of $2 \mathrm{~km}$ has experienced a decrease in DO during the rainy and dry season, the decomposition zone of Sunga Upper Brantas in Batu City is at a distance of $3 \mathrm{~km}$ to $6 \mathrm{~km}$ in the rainy season, and at a distance of 3-4 km dry season conditions, rehabilitation zone in the Brantas River in the Upper Batu City at a distance of $7 \mathrm{~km}$ to $8 \mathrm{~km}$ in the rainy season and at a distance of 5-11 km during the dry season and a re-purification zone, there was no purification zone at a distance of $11 \mathrm{~km}$ along the Brantas River in the Upper Batu City.
\end{abstract}

Keywords: distribution, prediction, purification zone, water pollution

\section{PENDAHULUAN}

Kota Batu merupakan salah satu lokasi hulu DAS Brantas dan berada pada sub DAS Ambang. Sub DAS Ambang terbagi menjadi 3 Sub DAS yaitu: Sub DAS Upper Brantas (Kota
Batu), Sub DAS Ambang (Kota Malang dan Kabupaten Malang) dan Sub DAS Bango (Kota Malang dan Kabupaten Malang). Posisi DAS Brantas Kota Batu yang berada di hulu meletakkan DAS Brantas sebagai penyangga ketersediaan air bagi masyarakat yang berada di hilir 
yang berdasarkan Peraturan Gubernur Jawa Timur No 61 Tahun 2010 menetapkan kualitas air sungai DAS Brantas berada pada Kelas I sebagai peruntukan air minum. Kondisi DAS Brantas menunjukkan sudah tidak mampu menerima tambahan beban pencemar.Dari 35 titik pengambilan contoh 1 titik dalam kondisi Baik yaitu Sumber Brantas, 19 titik berada dikondisi cemar ringan, 5 titik cemar sedang dan 10 titik tercemar berat. Indeks pencemaran terendah sebesar 0.92 dan tertinggi berada pada indeks 222,31. 13 titik pengambilan sampel ditentukan dengan alasan $50 \%$ dari jumlah pengambilan sampel awal yang merepresentasikan kualitas air sungai Brantas Kota Batu (Bambang Rahadi dkk, 2015).

Upaya monitoring dan evaluasi dapat dilakukan melalui pengambilan sampel air secara berkala dan menyeluruh untuk mendapatkan informasi perubahan kualitas air di tiga bagian DAS. Proses merealisasikan monitoring dan evaluasi masih menemui kendala yaitu besarnya biaya yang dibutuhkan untuk pengambilan sampel dan uji sampel laboratorium mengingat luasnya catchment area pada satu DAS. Alternatif solusi atas permasalahan tersebut adalah dengan melakukan prediksi terhadap kualitas air didaerah tengah/hilir melalui pendekatan pengambilan sampel di beberapa titik secara berurutan kemudian menentukan laju perubahan kualitas air sehingga kualitas air di titik berikutnya dapat diprediksi melalui berbagai metode.

Salah satu metode prediksi yang dapat digunakan adalah Neighborhood yang mana metode ini menghasilkan data spasial baru yang berbentuk polygon atau area dengan jarak tertentu dari data spasial yang menjadi masukannya. Data spasial titik akan menghasilkan data spasial baru yang berupa lingkaran-lingkaran yang mengelilingi titik-titik pusatnya. Untuk data spasial garis akan menghasilkan data spasial baru yang berupa poligonpoligon yang melingkupi garis-garis. Demikian pula untuk data spasial poligon berupa poligon-poligon yang lebih besar dan konsentris. Feature di dalam Sistem Informasi Geografis yang memanfaatkan metode Neighborhood adalah Inverse Distance Weigted (IDW) yang memiliki kelebihan karakteristik interpolasi dapat dikontrol dengan membatasi titik - titik masukan yang digunakan dalam proses interpolasi.

Pramono (2008), mengemukakan bahwa Metode IDW memberikan hasil interpolasi yang lebih akurat dari metode Kriging. Hal ini dikarenakan semua hasil dengan metode IDW memberikan nilai mendekati nilai minimum dan maksimum dari sampel data. Sedang metode Kriging terkadang memberikan hasil interpolasi dengan kisaran yang rendah. Opsi power dan jumlah sampel tidak memberikan perubahan yang signifikan pada hasil interpolasi.

\section{METODOLOGI}

\subsection{Pengumpulan Data}

Pengumpulan data meliputi data kualitas air pada musim hujan dan kemarat serta data spasial. Data kualitas air diambil secara primer dengan metode purposif samplingyaitu cara penentuan titik pengambilan sampel air dengan melihat pertimbangan-pertimbangan yang dilakukan oleh peneliti antara lain didasari atas kemudahan askes, biaya maupun waktu dalam penelitian (Yuliastuti, 2011). Penentuan titik pengambilan sampel air harus dapat mengambarkan karakteristik keseluruhan sungai, pada penelitian ini terdapat 13 titik pengambilan sampela yang dinotasikan dengan huruf A-M. Parameter kualitas air yang digunakan 
dalam penelitian ini adalah debit, $\mathrm{pH}$, DO, BOD, COD, TSS, TDS, PO4 dan NO3. Pengujian kualitas air dilakukan di Laboratorium Kualitas Air PT Jasa Tirta Kota Malang. Lokasi titik pengambilan sampel dapat dilihat pada Gambar 1.Pengumpulan data spasial berupa peta administratif Kota Batu dan peta jaringan sungai yang diperoleh dari BAPPEDA Kota Batu.

\subsection{Pengolahan Data}

Pengolahan data meliputi penentuan indeks pencemar air, prediksi distribusi pencemaran air dan penentuan hubungan jarak dengan kualitas air.

\subsubsection{Penentuan Indeks Pencemar Air}

Penentuan status mutu air sungai dalam penelitian ini dilakukan dengan menggunakan metode Indeks Pencemaran (Kepmen LH No. 115 Tahun 2003). Rumus perhitungan dengan metode Indeks Pencemaran adalah sebagai berikut :

$\mathrm{PI}_{\mathrm{j}}=\sqrt{\frac{\left(\mathrm{c}_{\mathrm{i}} / \mathrm{L}_{\mathrm{ij}}\right)_{\mathrm{M}^{2}}+\left(\mathrm{c}_{\mathrm{i}} / \mathrm{L}_{\mathrm{ij}}\right)_{\mathrm{B}}^{2}}{2}}$

dimana: $\mathrm{L}_{\mathrm{ij}}$ : kosentrasi parameter kualitas air yang dicantumkan dalam baku mutu peruntukan air (j), $C_{i}$ : konsentrasi parameter kualitas air (i), $\mathrm{PI}_{\mathrm{j}}$ : Indeks Pencemaran bagi peruntukan ( $\mathrm{j}$ ), $\left(\mathrm{C}_{\mathrm{i}} / \mathrm{L}_{\mathrm{ij}}\right)_{\mathrm{M}}$ : nilai $\mathrm{C}_{\mathrm{i}} / \mathrm{L}_{\mathrm{ij}}$ maksimum, dan $\left(\mathrm{C}_{\mathrm{i}} / \mathrm{L}_{\mathrm{ij}}\right)_{\mathrm{R}}$ : Nilai $\mathrm{C}_{\mathrm{i}} / \mathrm{L}_{\mathrm{ij}}$ rata-rata.

\section{Indeks Pencemaran ini}

mencerminkan ketercemaran sungai dengan membandingkannya dengan baku mutu sesuai kelas air yang ditetapkan berdasarkan Peraturan Pemerintah RI No. 82 Thn 2001. Sehingga dapat diperoleh informasi dalam menentukan dapat atau tidaknya air sungai dipakai untuk peruntukan tertentu sesuai kelas air.LangkahLangkah dalam penentuan status mutu air sungai dengan menggunakan metode Indeks Pencemaran sesuai dengan
Keputusan Menteri Lingkungan Hidup Nomor 115 Tahun 2003 tentang Pedoman Penentuan Status Mutu Air.Penentuan status pencemaran sungai. Kategori indek pencemaran dibagi menjadi empat yaitu kondisi baik dengan nilai $0 \leq \mathrm{Pij} \leq 1,0$, kondisi cemar ringan dengan nilai $1,0<\mathrm{Pij} \leq 5,0$, cemar sedang dengan nilai $5,0<\mathrm{Pij} \leq 10$, dan cemar berat Pij > 10,0.

\subsubsection{Prediksi \\ Pencemaran Air}

Tahapan selanjutnya adalah memasukkan data kualitas air ke database peta yang akan digunakan sebagai data dinput untuk analisis spasial. Selanjutnya adalah pembuatan visualisasi kualitas air hasil pengukuran. Entry Data bertujuan untuk bahan informasi yang selanjutnya diolah secara spaisal bersama dengan data spasial (peta). Pada tahap entry data, data yang dimasukkan yaitu data hasil pengujian kualitas air sungai Sungai Brantas Kota Batu dan juga Tahap selanjutnya dapat diperoleh sebaran pencemaran melallif proses analisa penyebaran pencemar dengan menggunakan metode IDW (Inverse Distance Weighted) dari datadata yang telah entry. Analisa penyebaran pencemar diperoleh dari proses pengolahan data kualitas air tanah menggunakan metode interpolasi IDW (Inverse Distance Weighted), untuk menganalisis dengan metode IDW data yang dibutuhkan yaitu titik sampel dalam bentuk point.shp, kemudian pengisian database variabel Y yang akan diinterpolasikan, dimana variabel berupa nilai parameter kualitas air dan berikutnya yaitu data batas area lokasi penelitian.

\subsubsection{Penentuan Zona Self Purification}

Hasil prediksi sebaran kualitas air yang diperoleh dari pengolahan data 
menggunakan IDW akan digunakan untuk mendapatkan hubungan antara jarak dengan kualitas air. Panjang sungai tempat studi adalah $11 \mathrm{~km}$ sehingga identifikasi dilakukan pada setiap $1 \mathrm{~km}$. Penentuan zona self purification didasarkan pada kondisi kadar DO pada air sungai yang terkategorikan sebagai berikut Hendrasarie dan Cahyarani (2008):

1. Zona Degradasi, dalam zona ini proses pencemaran dimulai dan mengalami puncak aktivitasnya. Benda-benda asing mulai mengalami degradasi. Karena terjadi proses dekomposisi atau penguraian, maka dibutuhkan oksigen, sehingga kadar oksigen terlarut dengan cepat makin berkurang.

2. Zona Dekomposisi, dari fase pertama proses pencemaran kemudian masuk ke dalam fase kedua ini, oksigen terlarut berkurang mulai dari 40 sampai $0 \%$. Akan tetapi pada akhir fase ini mulai naik lagi menjadi 40 $\%$.

3. Zona Rehabilitatif, dalam zona ini kadar oksigen terlarut meningkat berangsur-angsur sebaliknya dari 40 $\%$ ke atas. Kehidupan air secara mikroskopis mulai nampak. Air menjadi lebih jernih dibandingkan dengan zona-zona terdahulu.

4. Zona

Penjernihan

Kembali/Pemutihan, dalam zona ini yang merupakan fase terakhir dari rangkaian proses single pollution ditandai dengan meningkatnya oksigen terlarut secara maksimal sampai jenuh kembali yang diakibatkan dari berbagai mekanisme yang telah mampu normal kembali.

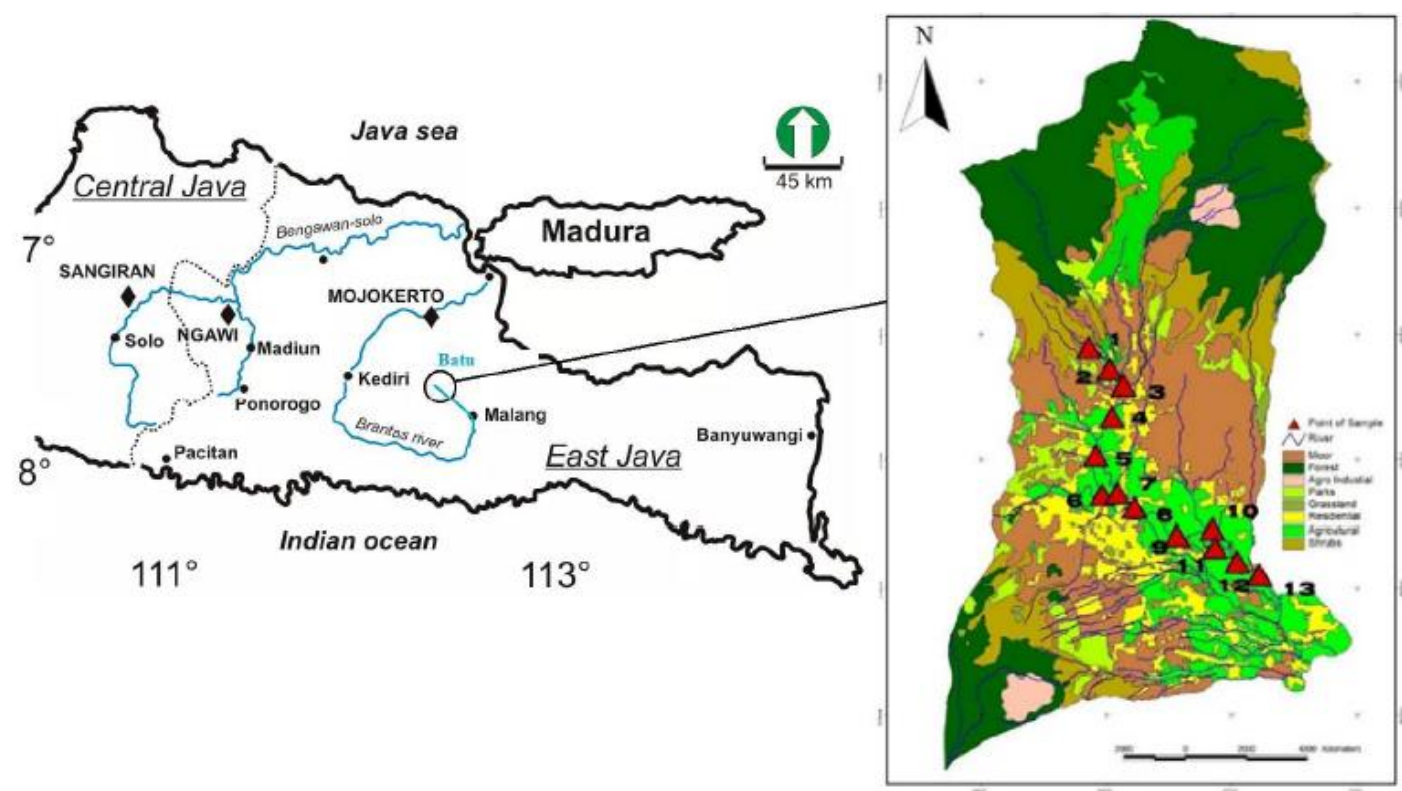

Gambar 1.

Lokasi Pengambilan Sampel Air Sungai

\section{HASIL DAN PEMBAHASAN}

\subsection{Kualitas Air Sungai Brantas} Kota Batu pada Musim Hujan dan Kemarau

Berdasarkan plotting perbandingan kualitas air pada musim hujan dan kemarau menunjukkan perubahan $\mathrm{pH}$ terbesar berada pada titik A dengan penurunan $\mathrm{pH}$ sebesar 1.2. Pada titik B sampai I terjadi penurunan $\mathrm{pH}$ dan pada titik $\mathrm{K}, \mathrm{L}$ dan $\mathrm{M}$ cenderung tidak ada penurunan $\mathrm{pH}$. Perubahan kadar DO pada musim hujan dan kemarau 
cenderung meningkat pada lokasi titik $\mathrm{E}$ sampai titik $M$ sedangkan pada titik A sampai E cenderung menurun. Apabila dibandingkan dengan standar baku mutu maka kualitas air pada musim kemarau cenderung lebih stabil berada pada angka 6. Hal ini menunjukkan bahwa terjadi perbaikan kualitas air berdasarkan parameter oksigen terlarutnya. Berdasarkan parameter BOD maka nilai BOD cenderung menurun yang mana pada musim kemarau angka BOD berada di rentang $5-10 \mathrm{mg} / \mathrm{L}$ sedangkan pada musim hujan terlihat bahwa kadar BOD fluktuatif. Hal ini juga mengindikasikan adanya perubahan kualitas air yang lebih baik.

Kadar COD pada musim hujan dan musim kemarau cenderung menurun dengan rentang nilai COD pada musim kemarau antara $20-30 \mathrm{mg} / \mathrm{L}$, berbeda dengan pada musim hujan yang cenderung fluktuatif antar titiknya. Hal ini menunjukkan adanya perubahan kualitas air yang lebih baik. Pada parameter TSS terlihat adanya peningkatan kadar TSS dari musim hujan dan musim kemarau, hal ini menunjukkan adanya peningkatan penggunaan air sungai yang menyebabkan penurunan kualitas air. adanya peningkatan kadar TDS dari musim hujan ke mausim kemarau. Hal ini sejalan dengan kadar TSS yang menunjukkan peningkatan, kadar TDS meningkat pada nilai antara $100-200$ $\mathrm{mg} / \mathrm{L}$, hal ini disebabkan adanya peningkatan pemanfaatan air sungai
Brantas Kota Batu. Fenomena yang sama ditunjukkan pada perubahan distribusi kadar NO3 yang cenderung menunjukkan peningkatan significant, sehingga hal ini mengindikasikan bahwa penggunaan pupuk kimia pada aktivitas pertanian Kota Batu semakin meningkat. Peningkatan kadar NO3 menyebabkan penurunan kualitas air karena tergantung bahan kimia yang masuk ke badan air.

Hasil juga menunjukkan perubahan distribusi phospat yang cenderung menurun pada musim hujan dan musim kemarau, namun penurunan tidak terlalu significant. Beberapa titik lokasi mengalami peningkatan sebesar $0.3 \mathrm{mg} / \mathrm{L}$ kadar phospat seperti titik D dan I. Hal ini tentunya mempengaruhi kualitas air sungai. Berdasarkan 8 parameter yang telah diuji maka dapat dilihat perubahan indeks pencemaran dan status pencemaran, terlihat bahwa nilai indeks pencemar cenderung meningkat, terjadi peningkatan significant pada titik D. Dari 13 titik pengambilan sampel diperoleh 1 titik mengalami peningkatan status pencemaran yaitu dari berat ke sedang, 1 titik sampel yang mengalami perubahan status pencemaran dari ringan ke sedang, 7 titik mengalami perubahan status dari sedang ke berat dan 4 titik sampel yang mengalami perubahan status dari ringan ke berat. Keseluruhan grafik perbandingan kualitas air dan indeks pencemar air dapat dilihat pada Gambar 3. 


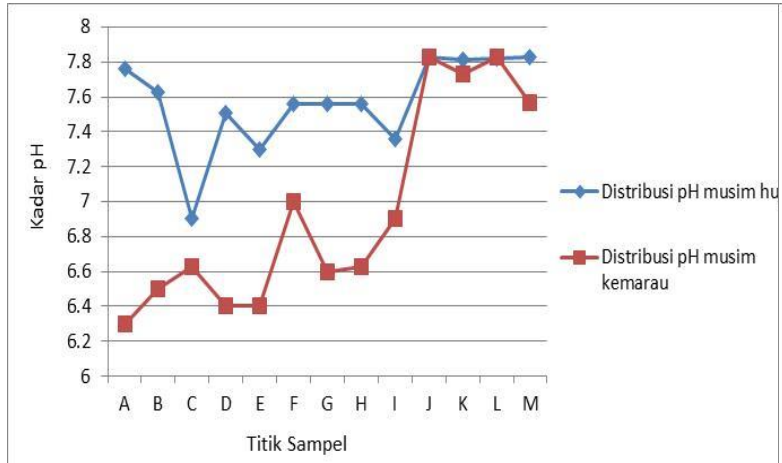

(a) Distribusi Kadar $\mathrm{pH}$

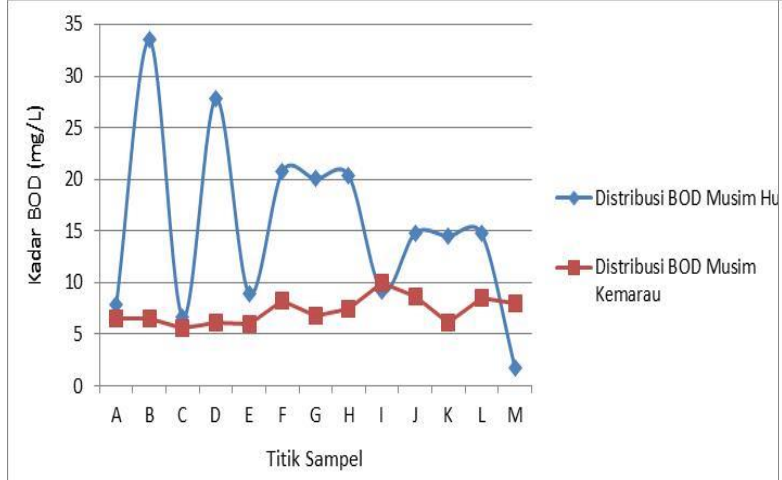

(c) Distribusi Kadar BOD

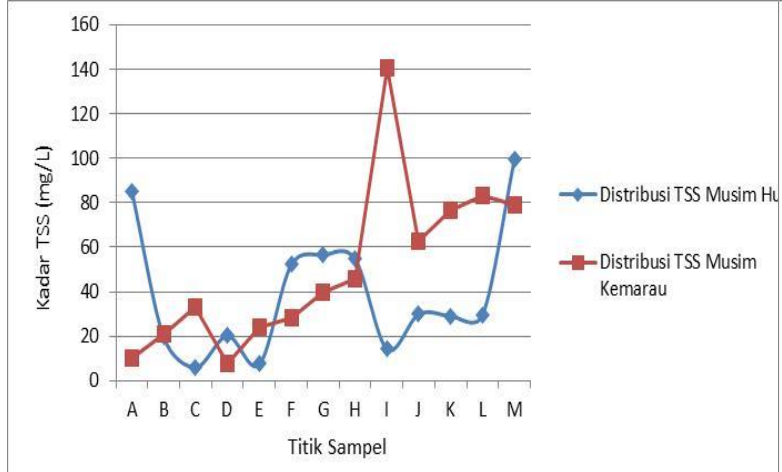

(e) Distribusi Kadar TSS

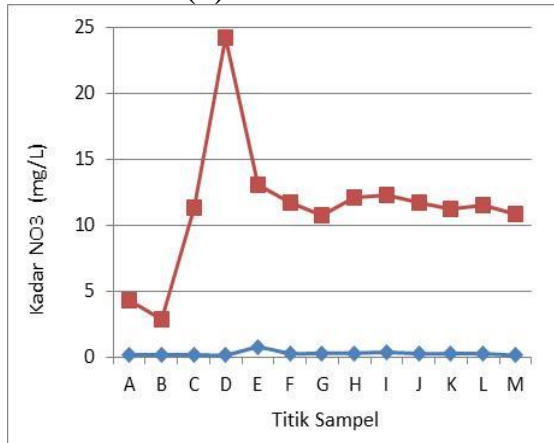

(g) Distribusi Kadar NO3

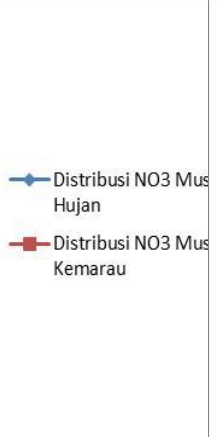

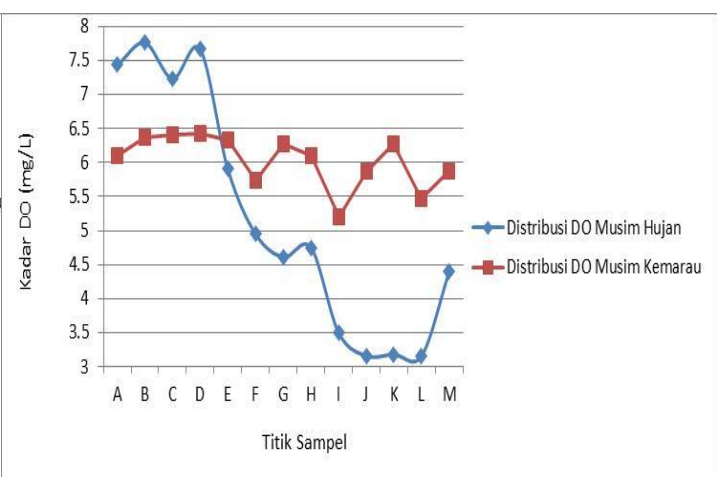

(b) Distribusi Kadar DO

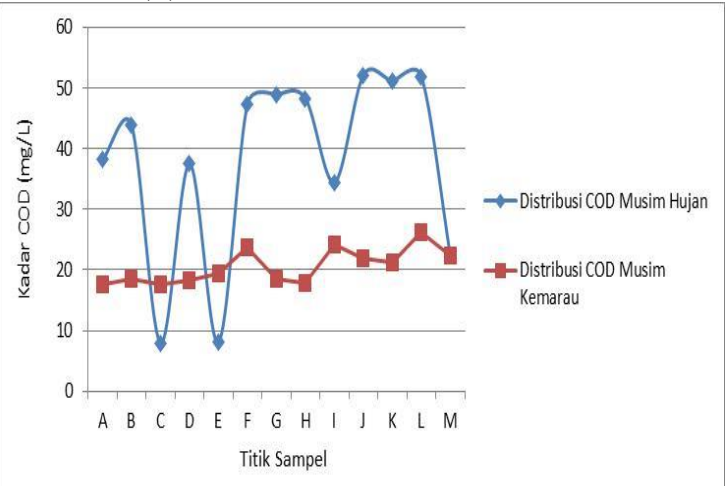

(d) Distribusi Kadar COD

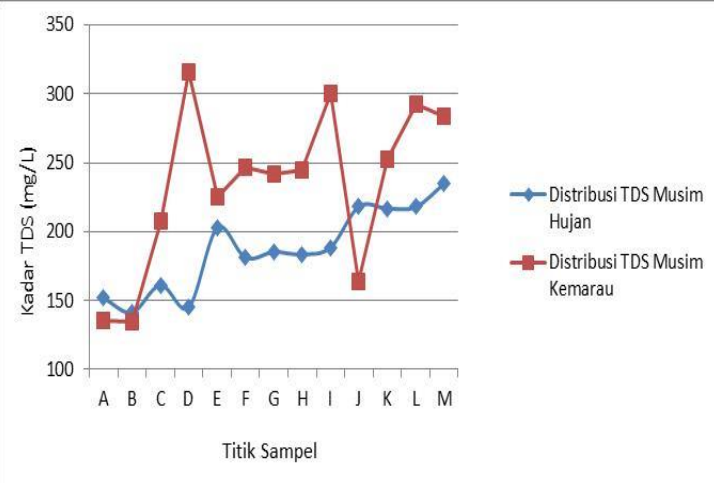

(f) Distribusi Kadar TDS

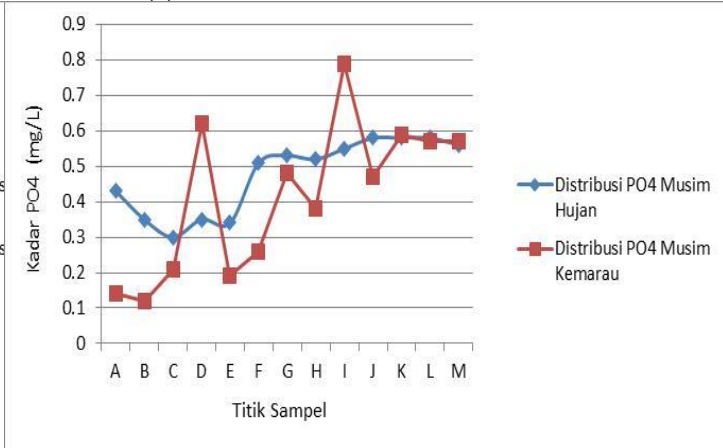

(h) Distribusi Kadar NO3 


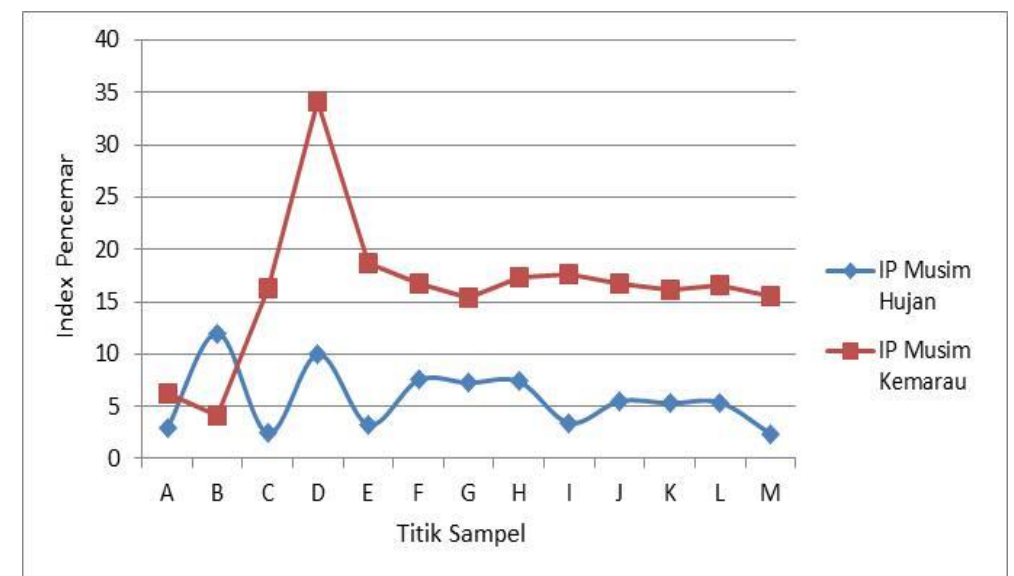

(i) Indeks Pencemaran Air

Gambar 3.

Perbedaan Kualitas Air Sungai Brantas Kota Batu pada Musim Hujan dan Kemarau

\subsection{Prediksi Penyebaran Kualitas Air Sungai Menggunakan IDW}

Metode IDW ini memiliki asumsi bahwa setiap titik input mempunyai pengaruh yang bersifat lokal yang berkurang terhadap jarak. Metode IDW umumnya dipengaruhi oleh inverse jarak yang diperoleh dari persamaan matematika. Nilai power pada interpolasi IDW ini menentukan pengaruh terhadap titik-titik yang lebih dekat sehingga menghasilkan permukaan yang lebih detail. Pengaruh akan lebih kecil dengan bertambahnya jarak dimana permukaan yang dihasilkan kurang detail dan terlihat lebih halus, jika nilai power diperbesar berarti nilai keluaran (output) sel menjadi lebih terlokalisasi dan memiliki nilai rata-rata yang rendah. Penurunan nilai power akan memberikan keluaran dengan rata-rata yang lebih besar, karena akan memberikan pengaruh untuk area yang lebih luas. jika nilai power diperkecil, maka dihasilkan permukaan yang lebih halus (Pasaribu, 2012). Water self purification merupakan kemampuan alami sungai untuk dapat mencairkan, mengurangi dan menghilangkan polutan, kotoran atau limbah yang masuk ke dalam sungai (Mehrdadi, et al, 2006). Kapasitas penguraian tersebut salah satunya tergantung pada beberapa faktor yang salah satunya adalah debit air (Fadly, 2008). Hasil prediksi penyabaran kualitas air menggunakan IDW dapat dilihat pada Gambar 4.

Berdasarkan hasil prediksi menggunakan IDW menunjukkan sebaran $\mathrm{pH}$ pada musim hujan semakin ke hilir terjadi kecenderungan ke arah basa namun pada Sungai Brantas yang melewati Kecamatan Junrejo mengalami penurunan, berbeda pada saat musim kemarau yang sebarannya bervariasi. Jika dilihat nilai $\mathrm{pH}$ pada musim hujan lebih tinggi dibandingkan dengan pada musim kemarau, pada musim hujan berada pada rentang $6.9-8.5$ sedangkan pada musim kemarau pada rentang 6.3 7.6. 


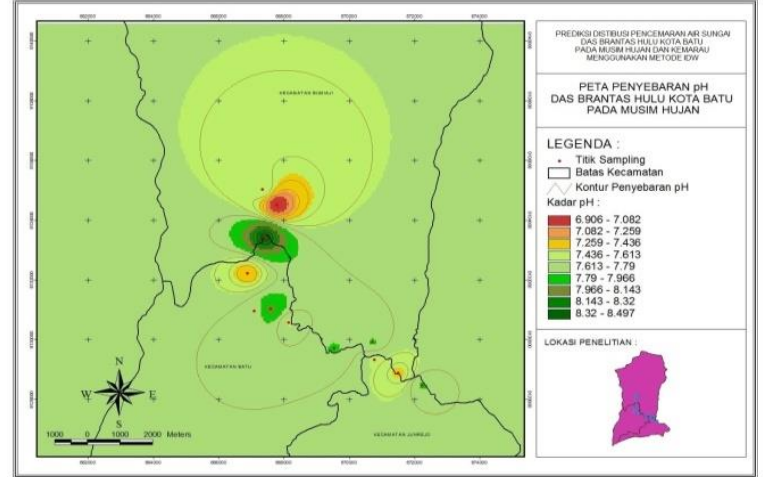

(a) pH Pada Musim Hujan

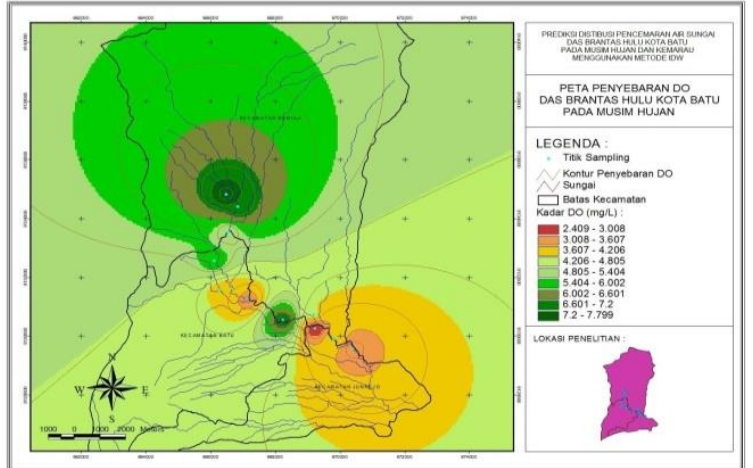

(c) DO Pada Musim Hujan

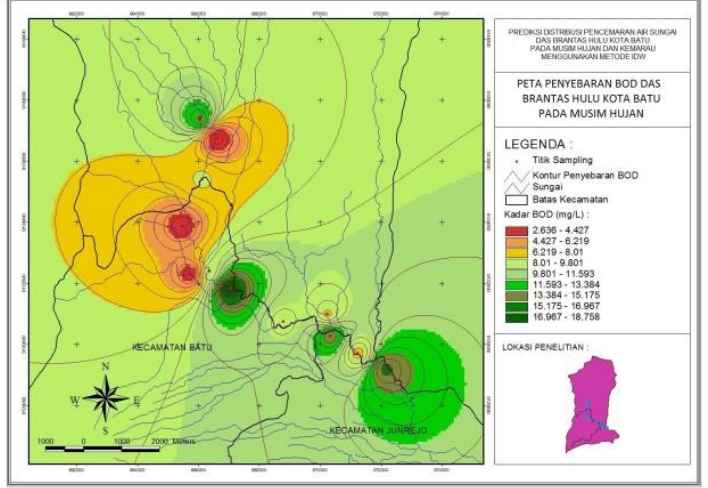

(e) BOD Pada Musim Hujan

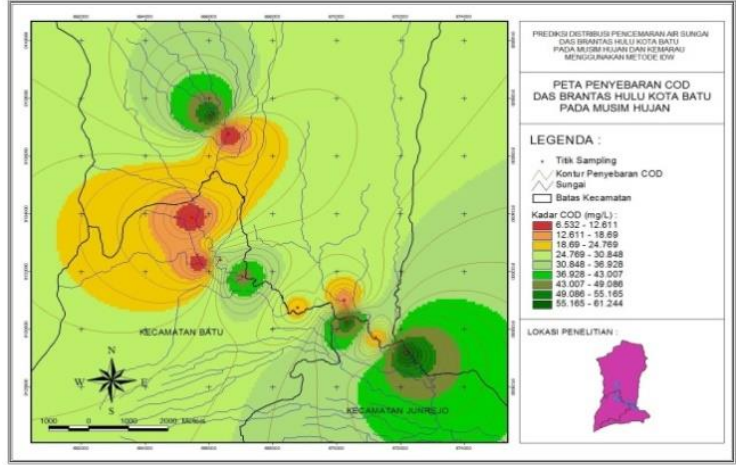

(g) COD Pada Musim Hujan

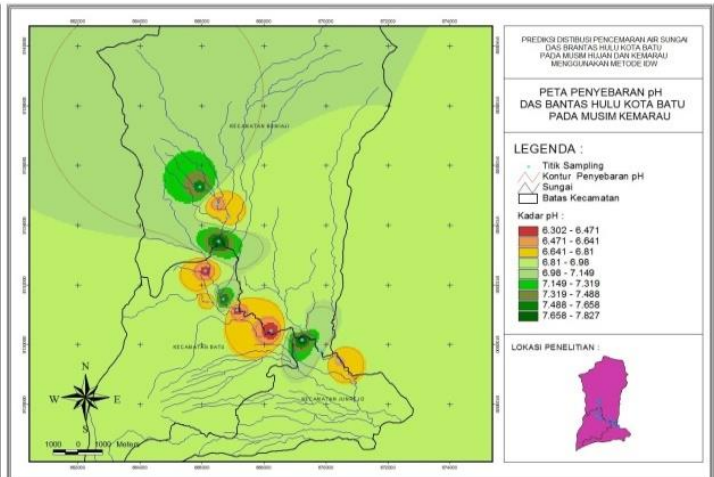

(b) pH Pada Musim Kemarau

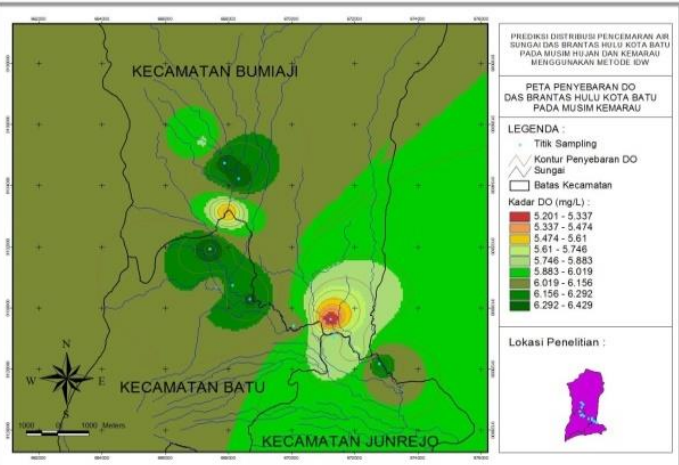

(d) DO Pada Musim Kemarau

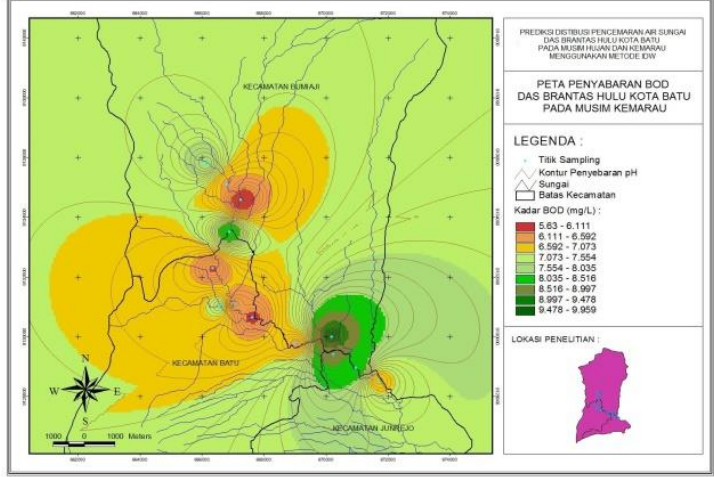

(f) BOD Pada Musim Kemarau

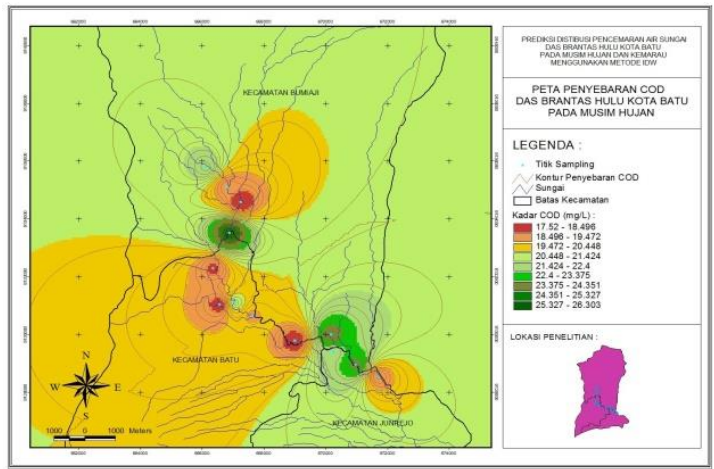

(h) COD Pada Musim Kemarau 


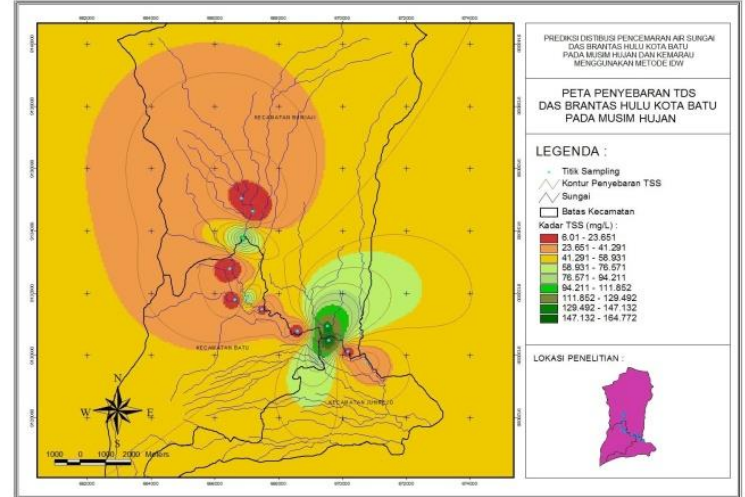

(i) TSS Pada Musim Hujan

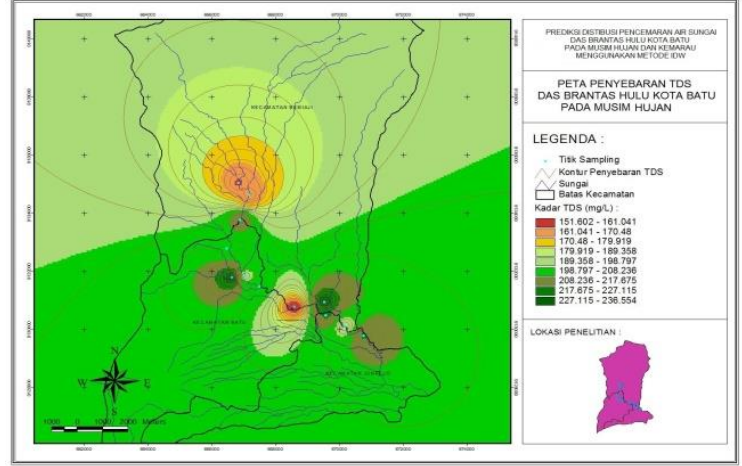

(k) TDS Pada Musim Hujan

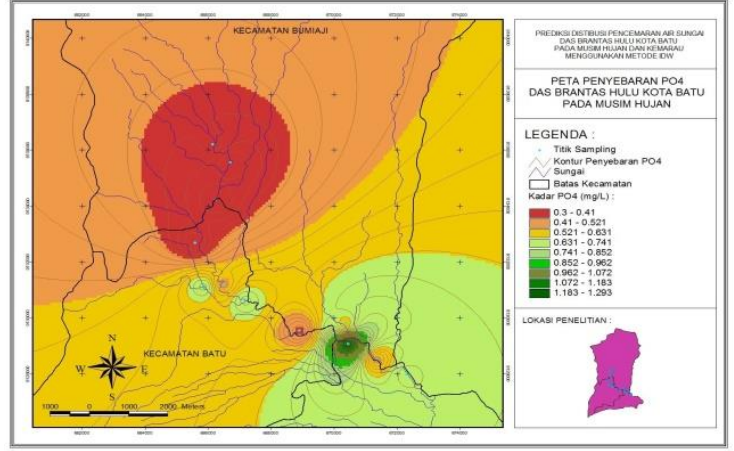

(m) PO4 Pada Musim Hujan

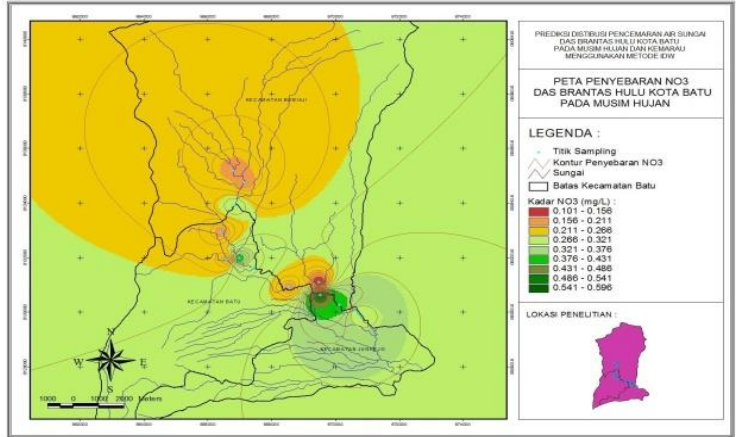

(o) NO3 Pada Musim Hujan

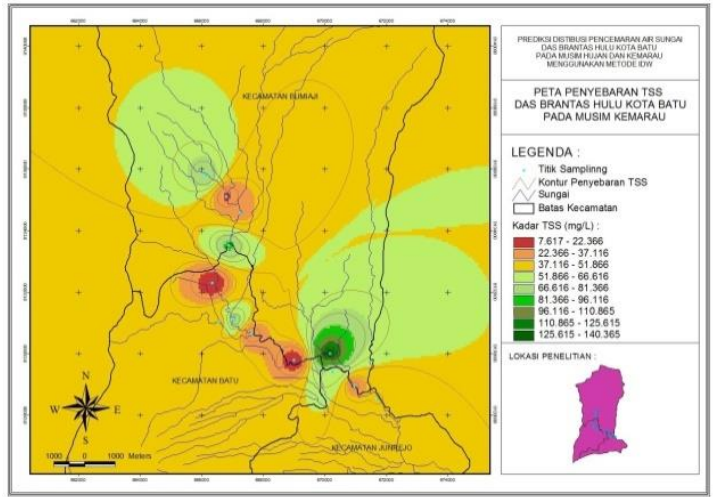

(j) TSS Pada Musim Kemarau

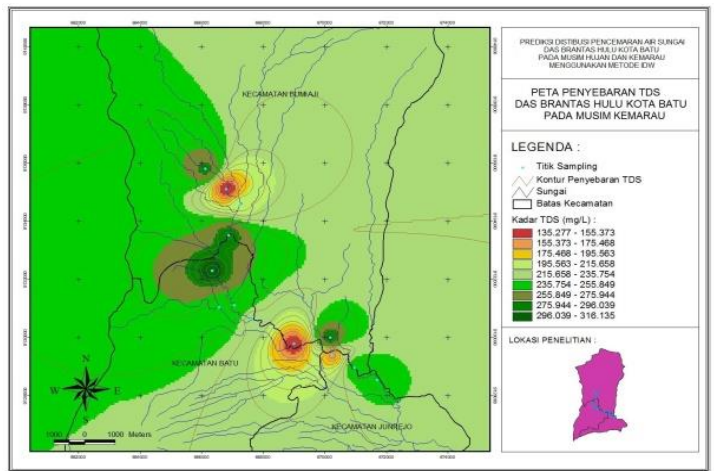

(1) TDS Pada Musim Kemarau

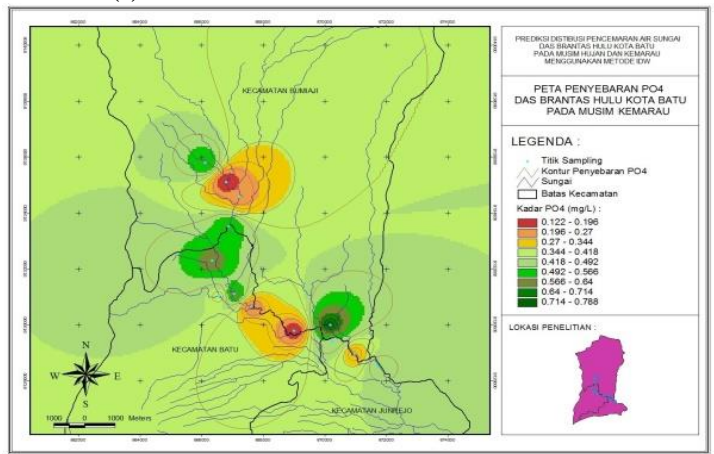

(1) PO4 Pada Musim Kemarau

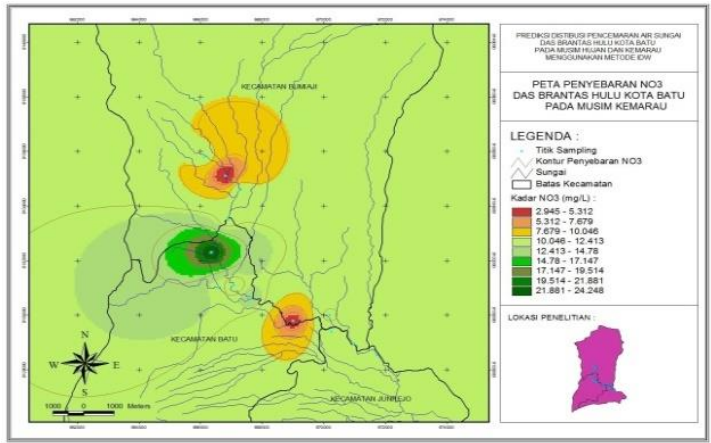

(p) NO3 Pada Musim Kemarau

Gambar 4.

Prediksi Penyebaran Kualitas Air Sungai Brantas Kota Batu Menggunakan IDW

Hasil interpolasi spasial pada kadar DO menunjukkan bahwa sebaran kadar
DO pada musim hujan semakin ke hilir nilai DO semakin menurun dengan 
rentang nilai 2.4 sampai $7.8 \quad \mathrm{mg} / \mathrm{L}$ sedangkan pada musim kemarau menunjukkan rentang lebih sempit sebesar $5.2-6.4 \mathrm{mg} / \mathrm{L}$ dengan sebaran lebih variasi. Hal ini menunjukkan bahwa semakin besar debit sungai dapat memberikan suplai oksigen lebih besar.

Sebaran kadar BOD pada Sungai Brantas pada musim hujan menunjukkan semakin ke daerah hilir nilai BOD semakin tinggi dengan rentang nilai BOD sebesar $2.6-18.7 \mathrm{mg} / \mathrm{L}$, sedangkan pada musim kemarau juga menunjukkan sebaran yang cenderung peningkatan BOD ke arah hilir namun dengan rentang kadar BOD lebih rendah dibandingkan musim kemarau dengan rentang nilai $5.63-9.95 \mathrm{mg} / \mathrm{L}$. Kecenderungan peningkatan nilai BOD pada area hilir disebabkan karena adanya peningkatan aktivitas manusia yang mengakibatkan peningkatan beban pencemar yang diterima Sungai Brantas.

Nilai COD pada musim hujan menunjukkan sebaran semakin ke hilir cenderung semakin meningkat dengan rentang nilai lebih tinggi dibandingkan pada musim kemarau dengan nilai 6.53 $61.24 \mathrm{mg} / \mathrm{L}$. Pada musim kemarau menunjukkan nilai rentang lebih rendah sebesar 17.52 - $26.3 \mathrm{mg} / \mathrm{L}$ dengan kecenderungan semakin ke hilir mengalami peningkatan. Nilai TSS pada musim hujan dan musim kemarau cenderung tidak mengalami perbedaan yang signifikan, dimana untuk musim hujan rentang nilai TSS berada pada nilai $6.01-164.772 \mathrm{mg} / \mathrm{L}$ sedangkan pada musim kemarau berada pada rentang $7.6-140 \mathrm{mg} / \mathrm{L}$ dengan kecenderungan variasi yang significant ke arah hilirnya. Apabila dibandingkan untuk setiap titiknya kadar TSS pada musim kemarau memiliki kadar lebih tinggi dibandingkan pada musim hujan.

Nilai TDS pada musim hujan memiliki sebaran kecenderungan meningkat pada area hilir dengan nilai rentang 151.6 - $236.5 \mathrm{mg} / \mathrm{L}$, berbeda dengan kondisi pada musim kemarau sebaran nilai TDS menunjukkan semakin ke hilir semakin menurun dengan nilai rentang lebih tinggi dibanding musim hujan yaitu pada nilai 135.27 - 316.14 $\mathrm{mg} / \mathrm{L}$. Kadar PO4 di Sungai Brantas Kota Batu memiliki sebaran semakin kehilir mengalami peningkatan dengan nilai rentang $0.3-1.29 \mathrm{mg} / \mathrm{L}$ pada musim hujan sedangkan pada musim kemarau kadar PO4 memiliki sebaran lebih bervariatif dengan rentang nilai PO4 lebih rendah sebear $0.1-0.77$ $\mathrm{mg} / \mathrm{L}$.

Kadar NO3 pada musim hujan memiliki kecenderungan semakin kehilir semakin tinggi kadar NO3 hal ini disebabkan adanya pembuangn limbah cair ke Sungai semakin besar, nilai rentang kadar NO3 pada musim hujan sebesar $0.1-0.6 \mathrm{mg} / \mathrm{L}$. Dibandingkan dengan musim kemarau kadar NO3 berbanding jauh dengan kadar pada musim hujan yaitu berkisar pada nilai $2.9-24.25 \mathrm{mg} / \mathrm{L}$ dengan kecenderungan semakin ke hilir semakin rendah.

\subsection{Hubungan Jarak dan Kualitas Air untuk Penentuan Zona Self Purification}

Berdasarkan prediksi penyebaran kandungan kimia pada kualitas air Sungai Brantas Kota Batu maka selanjutnya adalah menampilkan bentuk data hubungan antara jarak terhadap kandungan kimia kualitas air. Hubungan jarak dengan kualitas air yang ditunjukkan hanya sampai pada jarak 11 $\mathrm{km}$ disesuaikan dengan panjang sungai sesuai lokasi pengambilan sampel (keseluruhan dapat dilihat pada Gambar 5). Pada hubungan kadar $\mathrm{pH}$ dengan jarak diperoleh bentuk cenderung stabil, kondisi $\mathrm{pH}$ pada $11 \mathrm{~km}$ Sungai Brantas Hulu Kota Batu tidak terlalu menunjukkan perbedaan yang signifikan baik pada musim hujan dan musim 
kemarau.Kondisi kandungan oksigen pada jarak $11 \mathrm{~km}$ menunjukkan bahwa pada musim hujan mengalami penurunan, yang menunjukkan kualitas air semakin ke hilir mengalami penurunan. Berbeda dengan musim kemarau kondisi kandungan oksigen terlarut cenderung stabil atau tidak mengalami perubahan yang significant, dikarenakan debit air yang masuk relatif tidak berubah. Hubungan BOD terhadap jarak pada musim hujan menunjukkan signifikasi yang relatif tinggi, pada $4 \mathrm{~km}$ pertama mengalami penurunan sedangkan pada jarak setelahnya mengalami peningkatan. Sedangkan pada musim kemarau kecenderungan hubungan kadar BOD lebih stabil, ada perubahan kadar BOD yang lebih tinggi ke arah hilir pada jarak ke 5-11 km.

Pola sebaran COD pada Sungai Brantas Hulu Kota Batu menunjukkan sebaran yang sama dengan sebaran COD yaitu pola signifikasi yang relatif tinggi, pada $4 \mathrm{~km}$ pertama mengalami penurunan sedangkan pada jarak setelahnya mengalami peningkatan. Sedangkan pada musim kemarau kecenderungan hubungan kadar BOD lebih stabil, ada perubahan kadar COD yang lebih tinggi ke arah hilir pada jarak ke $5-11 \mathrm{~km}$.Hubungan TSS pada $11 \mathrm{~km}$ jarak Sungai Brantas Hulu Kota Batu antara musim hujan dan musim kemarau menunjukkan pola yang hampir sama, terjadi peningkatan kadar TSS pada jarak $3 \mathrm{~km}$, kemudian mengalami penurunan pada jarak $4 \mathrm{~km}$ dan perlahan peningkatan sampai jarak $8 \mathrm{~km}$ dan meningkat jauh pada jarak $9 \mathrm{~km}$, sedangkan pada jarak $10-11 \mathrm{~km}$ mengalami penurunan yang sangat tajam. Peningkatan dan penurunan TSS pada beberapa titik dipengaruhi oleh kondisi penggunaan lahan disekitar area, titik yang mengalami peningkatan tajam diperkirakan karena kondisi lahan pada titik tersebut masih didominasi oleh lahan kosong.

Pola sebaran TDS pada Sungai Brantas Hulu Kota Batu pada musim hujan dan musim kemarau menunjukkan pola yang relatif sama, kadar TDS mengalami peningkatan pada jarak $1-4$ $\mathrm{km}$ kemudian mengalami penurunan pada jarak $5-8 \mathrm{~km}$ dan kemudian mengalami peningkatan kembali pada jarak 9-11 km. Kondisi kandungan NO3 pada musim hujan dan kemarau menujukkan sebaran yang sangat berbeda, kandungan NO3 pada musim hujan lebih stabil dibandingkan musim kemarau dengan nilai lebih rendah dibandingkan dengan musim kemarau. Pola NO3 pada musim kemarau mengalami peningkatan yang sangat signifikan pada jarak $4 \mathrm{~km}$ dan mengalami penurunan yang sangat tajam pada jarak 8 km. Kadar NO3 yang cukup tinggi dipengaruhi oleh dominasi aktivitas pertanian di sekitar sungai yang diindikasikan ada pengaruh aktivitas pencucian tanaman di sekitar sungai yang menyebabkan pupuk cair yang digunakan tertinggal pada aliran sungai.

Hubungan jarak dengan kadar PO4 pada Sungai Brantas menunjukkan pola yang sedikit berbeda, pada musim hujan pada jarak 1-4 km mengalami penurunan kemudian pada jarak 5-7 km mengalami peningkatan. Sedangkan pada musim kemarau oada jarak 1-4 km mengalami peningkatan, jarak 5-8 km mengalami penurunan. Pola yang sama hanya ditunjukkan pada jarak 8 dan $10 \mathrm{~km}$ mengalami penurunan yang sangat tajam dan diikuti peningkatan pada jarak 9 dan $11 \mathrm{~km}$. Fosfor Merupakan bentuk dari unsur fosfor yang terdapat di dalam air yang dapat berasal dari detergent sisa cucian, kotoran hewan, pupuk yang terlarut, dan lain-lain berfungsi sebagai hara untuk tanaman air, dan dapat mengakibatkan proses eutrofikasi (Rahayu, 2010). 


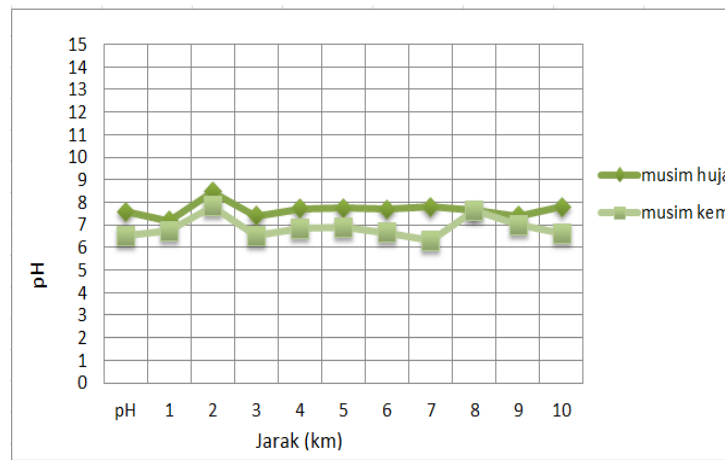

(a) Hubungan $\mathrm{pH}$ dengan Jarak

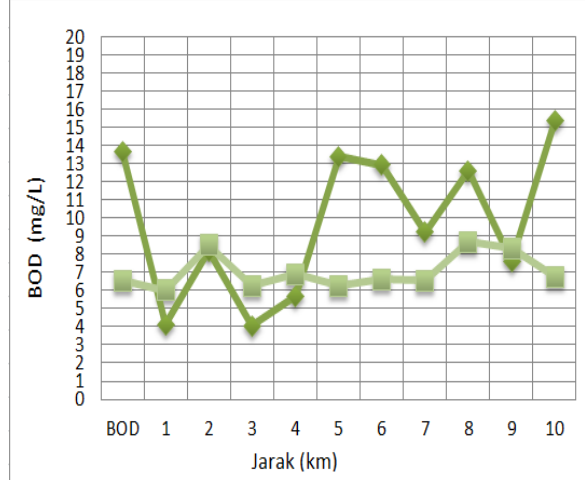

(c) Hubungan BOD dengan Jarak

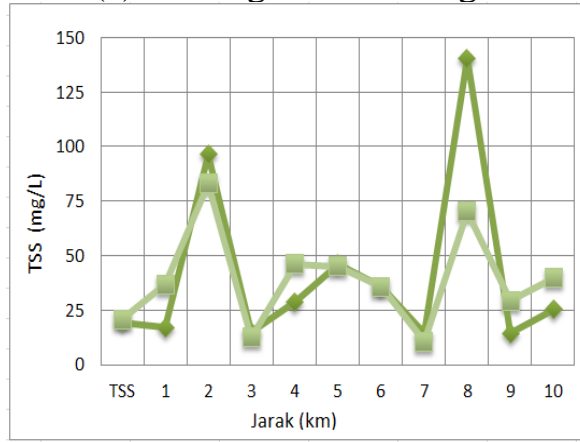

(e) Hubungan TSS dengan Jarak

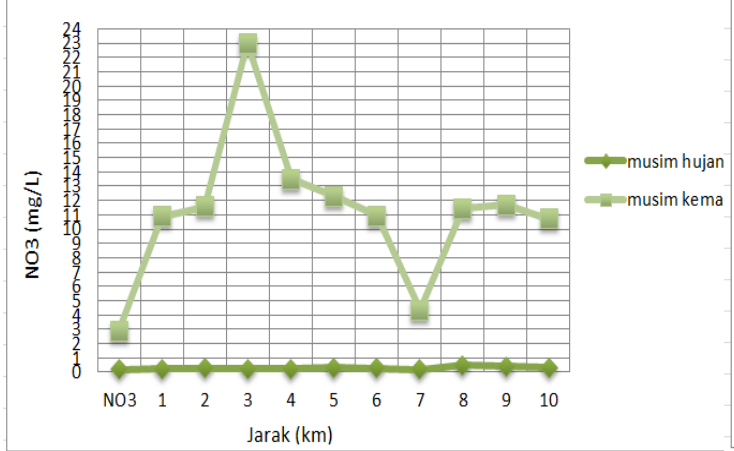

(g) Hubungan NO3 dengan Jarak

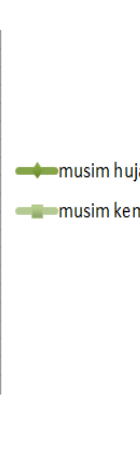

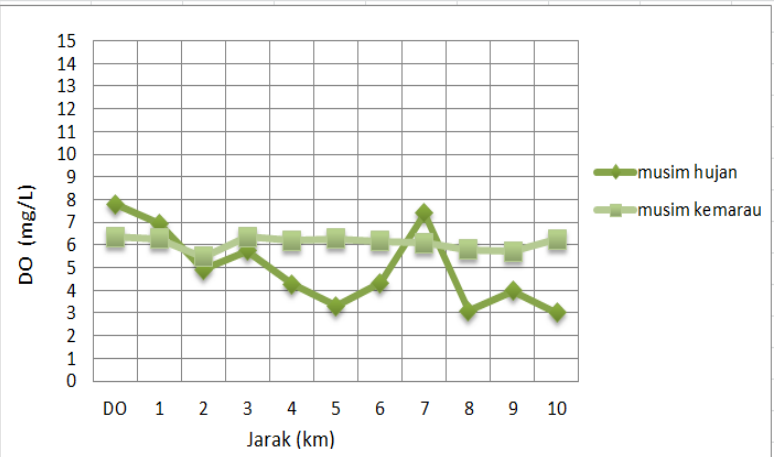

(b) Hubungan DO dengan Jarak

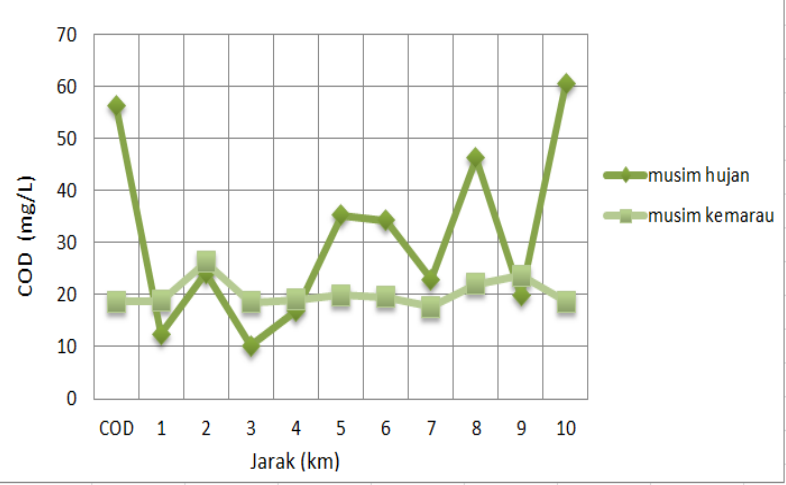

(d) Hubungan COD dengan Jarak

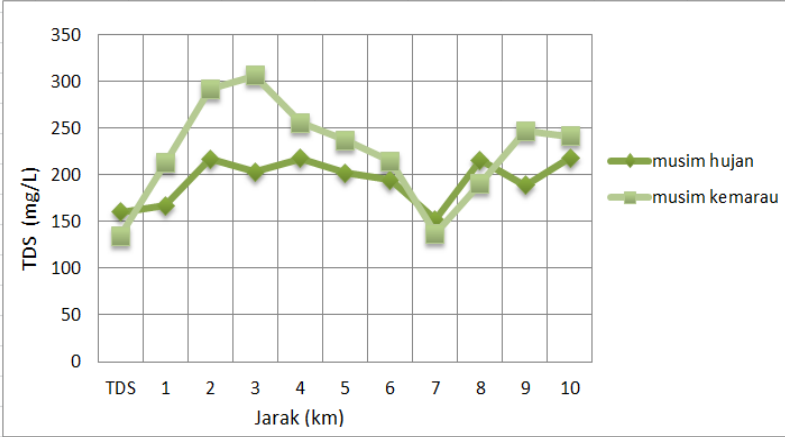

(f) Hubungan TSS dengan Jarak

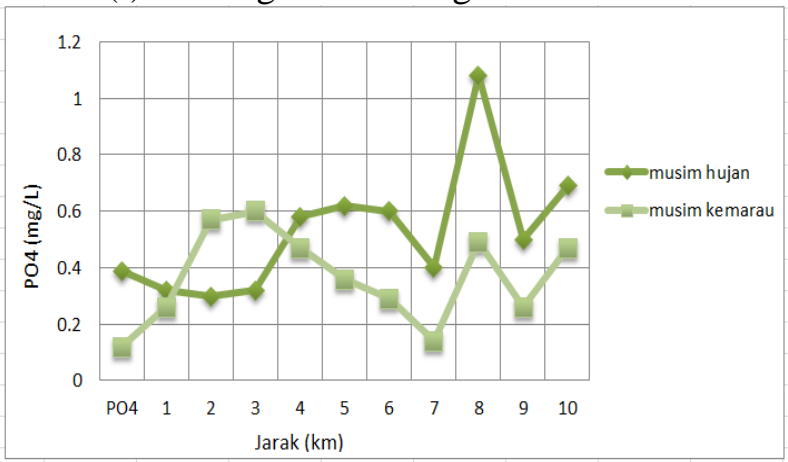

(h) Hubungan PO4 dengan Jarak

Gambar 5.

Hubungan Jarak dengan Kualitas Air 
Zona degradasi Sungai Branats Hulu Kota Batu pada jarak $2 \mathrm{~km}$ sudah mengalami penurunan DO pada musim hujan dan kemarau.Zona dekomposisi Sunga Brantas Hulu Kota Batu terdapat pada jarak $3 \mathrm{~km}$ sampai $6 \mathrm{~km}$ pada musim hujan, dan pada jarak 3-4 km kondisi musim kemarau.Zona rehabilitasi di Sungai Brantas Hulu Kota Batu pada jarak $7 \mathrm{~km}$ sampai $8 \mathrm{~km}$ pada musim hujan dan pada jarak 5-11 km pada musim kemarau.Zona penjernihan kembali tidak ditemukan zona penjernihan kembali pada jarak $11 \mathrm{~km}$ sepanjang Sungai Brantas Hulu Kota Batu.

\section{SIMPULAN DAN SARAN}

Kesimpulan yang diperoleh dari penelitian ini adalah dari 13 titik pengambilan sampel diperoleh 1 titik mengalami peningkatan status pencemaran pada musim hujan ke musim kemarau yaitu dari berat ke sedang, 1 titik sampel yang mengalami perubahan status pencemaran dari ringan ke sedang, 7 titik mengalami perubahan status dari sedang ke berat dan 4 titik sampel yang mengalami perubahan status dari ringan ke berat.Zona degradasi Sungai Branats Hulu Kota Batu pada jarak $2 \mathrm{~km}$ sudah mengalami penurunan DO pada musim hujan dan kemarau, zona dekomposisi Sunga Brantas Hulu Kota Batu terdapat pada jarak $3 \mathrm{~km}$ sampai $6 \mathrm{~km}$ pada musim hujan, dan pada jarak 3-4 km kondisi musim kemarau, zona rehabilitasi di Sungai Brantas Hulu Kota Batu pada jarak $7 \mathrm{~km}$ sampai $8 \mathrm{~km}$ pada musim hujan dan pada jarak 5-11 km pada musim kemarau dan zona penjernihan kembali tidak ditemukan zona penjernihan kembali pada jarak $11 \mathrm{~km}$ sepanjang Sungai Brantas Hulu Kota Batu.

\section{DAFTAR PUSTAKA}

Bambang Rahadi, Fajri Anugroho, Euis Elih N. 2015. Model Daya Tampung Lingkungan sebagai Program Pengelolaan Lingkungan dalam Upaya Perlindungan Daerah Sungai. Laporan Penelitian PUPT LPPM UB.

Fadly, N, Aliefia. 2008. "Daya Tampung dan Daya DUkung Sungai Ciliwung serta Strategi Pengelolaanya". Thesis Program Pasca Sarjana. Fakultas Teknik-UI. Depok.

Hendrasarie dan Cahyarani. 2010. Kemampuan Self Purification KaliSurabaya, Ditinjau dari ParameterOrganik Berdasarkan Model MatematisKualitas Air. Jurnal Ilmiah Teknik Lingkungan. 02 : 01 , 2010. Surabaya : Fakultas Teknik Sipil dan Perencanaan, Universitas Pembangunan Nasional "Veteran" Jawa Timur.

Keputusan Menteri Lingkungan Hidup No 115 Tahun 2003 tentang Pedoman Penentuan Status Mutu Air.

Mehrdadi, N, Ghobadi M, Nasrabadi T, Hoveidi H. 2006. Evaluation of The Quality and Self Purification Potential Of Tajan River Using Qual2e Model. Iran, J. Environ. Health.Sci. Eng, 2006. Vol.3 No.3, pp 199-204.

Pasaribu, Juwita dan Nanik S. 2012. Perbandingan Teknik Interpolasi DEM SRTM Dengan Metode Inverse Distance Weighted (IDW), Natural Neighbor dan Spline. Jurnal Penginderaan Jauh Vol. 9 No. 2 Desember 2012 : 126-139. 
Pramono, G. 2008. Akurasi Metode IDW Dan Kriging Untuk Interpolasi Sebaran Sedimen Tersuspensi. Forum Geografi, Vol. 22, No. 1, Juli $2008: 97-110$.
Yuliastuti, E. 2011. "Kajian Kualitas Air Sungai Ngringo Karanganyar Dalam Upaya Pengendalian Pencemaran Ai”r. Program Magister Ilmu Lingkungan. Universitas Diponegoro Semarang. 